\title{
Human Pathogens as Capstone Application of the Economics of Information to Convention on Biological Diversity: The Receptivity of Research Scientists
}

\author{
Joseph Henry Vogel ${ }^{1}$, Barbara Ann Hocking ${ }^{2}$, Claribel Fuentes-Rivera ${ }^{3}$, Omar Oduardo-Sierra ${ }^{4}$ \\ \& Ana R. Zubiaurre \\ ${ }^{1}$ Department of Economics, University of Puerto Rico-Rio Piedras, USA \\ ${ }^{2}$ Honorary Research Fellow, Riawunna Institute, Australia \\ ${ }^{3}$ Department of Interdisciplinary Science, University of Puerto Rico-Rio Piedras, USA \\ ${ }^{4}$ Department of Political Science, University of Puerto Rico-Rio Piedras, USA \\ ${ }^{5}$ Department of Applied Economics, Universidad de las Palmas de Gran Canaria, Spain \\ Correspondence: Joseph Henry Vogel, Department of Economics, University of Puerto Rico, PO Box 23345, \\ San Juan, Puerto Rico, USA. Tel: 1-787-764-0000, ext. 2451. E-mail: josephvogel@usa.net
}

Received: December 3, 2012 Accepted: March 4, 2013 Online Published: March 26, 2013

doi:10.5539/ijb.v5n2p121 URL: http://dx.doi.org/10.5539/ijb.v5n2p121

Support has been provided by the Linkage International Grant of the Australian Research Council (LX0881935). Any opinions, findings, conclusions or recommendations expressed are those of the authors and do not necessarily reflect the views of the ARC (Sponsoring information)

\begin{abstract}
Economics provides powerful abstraction. To deploy that power the object of resource allocation must be correctly identified. The 1992 United Nations Convention on Biological Diversity (CBD) and the 2010 Nagoya Protocol (NP) define "genetic resources" as "material" despite being immaterial. The error has generated unresolved and contentious issues surrounding access and the fair and equitable sharing of benefits arising from utilization (ABS). A correct classification of the object as "natural information" invites "the economics of information" with radically different implications for policy: bounded openness, tracking utilization through disclosure in patents and royalties shared proportional to habitat among "countries of origin." Human pathogens are a peculiar case of applying the same economics of information where the overarching objective is inverted: in situ eradication rather than in situ conservation. Because time translates into lives, incentives must be institutionalized for speedy entry of samples into the international medical research stream with sharing in benefits for utilization on a nuanced first-to-submit principle. As such the benefits would be greatest for just one country of origin which could then determine incentives within its scientific community. Researchers who have published work on pathogens in the first year of the NP (2011) were surveyed. The results support the application of the economics of information to ABS policy.
\end{abstract}

Keywords: bounded openness, access, benefit sharing

\section{Introduction}

Access to pathogens is crucial for agriculture, industry and public health. Pathogens fall under the 1992 United Nations Convention on Biological Diversity (CBD), which stipulates a "fair and equitable sharing of benefits arising from the utilization of genetic resources," abbreviated as ABS. The first ten Conferences of the Parties (COP) to the CBD have not resolved any of the contentious issues associated with ABS (Kamau et al., 2010) and frustrations have become palpable among stakeholders. Because ABS is an additional burden to existing health regulations, industrialized countries have argued forcefully to exclude pathogens from the CBD (Buck and Hamilton, 2011). They have not succeeded as evidenced in Article 8 (b) of the 2010 UN Nagoya Protocol to ABS (NP) which establishes that each Party "[i]n the development and implementation of its access and benefit-sharing legislation" include genetic resources which pose "present or imminent emergencies that threaten human, animal or plant health..." Nevertheless, sovereignty is not absolute (Abbott, 2010) and Parties can defer 
to The World Health Organization (WHO) under Art. 4.4 should that body achieve an ABS agreement that is "consistent with, and does not run counter to the objectives of the Convention and this Protocol."

Six months after COPX, the World Health Assembly (2011) launched the Pandemic Influenza Preparedness Framework (PIPF) for the sharing of influenza viruses. The principal benefit for providing countries pathogens would be affordable access to resulting vaccines (Lawson \& Hocking, 2010). Although the quid pro quo of one access for another appears "consistent with [and not] counter to" the objectives of CBD and NP, incentives among stakeholders become distorted. For countries with poor governance, health care workers have few incentives to expedite samples into the international stream of Research and Development (R\&D). Even for those with good governance, the sharing of a benefit among countries for submission of the same genetically sequenced sample dilutes the incentive to be the first to submit. Such deductions are somewhat counterintuitive and derive from the abstract reasoning that is the hallmark of economic thinking. More specifically, the argument flows from the economics of information, a field recognized in both the 1982 and 2001 Nobel Memorial Prizes.

\subsection{Applying the Economics of Information to Genetic Resources}

Garrett Hardin (1993) observed that a successful theory will compress the relevant literature and make much of it useless. Not surprisingly, resistance accompanies scientific revolutions (Kuhn, 1961). A solution to the contentious issues associated with ABS lies in the economics of information (Vogel et al., 2011). To apply that economics, one must recognize that genes are information. Although the assertion is Kuhnian "normal science" ever since F. W. Crick's "Central Dogma of Molecular Biology" (1970), Art. 2 of the CBD misdefines genetic resources as "material." Once the foundational error is corrected, three questions emerge in the spirit of Hardin and Kuhn. How does the economics of information compress the copious literature on ABS? What is the evidence of resistance to the application? How do we adapt the policy implications for the peculiar case of pathogens? One paragraph to answer each question is good evidence of compression.

Compression begins with the asymmetrical cost structure of information: the fixed costs of an innovation can be enormous while the marginal costs of reproduction are trivial. For immaterial goods, the salubrious effect of competition--celebrated ever since Adam Smith--is neither efficient nor equitable. Innovators are discouraged by copycats who bear none of the fixed costs. To make innovations more viable, time-limited monopolies are a solution. Given the conceptual reduction of genetic resources to natural information, any analogy with conservation is really a homology (Vogel, 2009). To make conservation more viable, time-limited oligopolies are part of the solution. Such a biodiversity cartel (Vogel, 1997; Vogel et al., 2000) would employ the theoretical construct of "bounded openness" in the political science of the commons (May, 2010). Biological samples would flow unencumbered by ABS regulations but industries would be obligated to disclose utilization in patent applications and pay royalties when commercially successful. The benefits would be shared among countries of origin, proportional to habitat.

Resistance to policy implication of the economics of information is evidenced by decades of studious ignorance to the well-published argument (Oduardo-Sierra et al., 2012) and institutionalized exclusion (West, 2012). As of this writing, the most recent example is The Explanatory Guide to the Nagoya Protocol on Access and Benefit-Sharing_Draft 3.0 (IUCN Environmental Policy and Law, 2012) which observes: "competition between the different provider States/ILCs [Indigenous and Local Communities] sharing the same genetic resources/traditional knowledge associated with genetic resources...will weaken their position in the negotiation of MAT [mutually agreed terms], and might lead to a race to the bottom regarding ABS requirements" (p. 19). As a preemptive strike against any inference to cartelize, The Guide reaffirms a narrow interpretation of sovereignty: "It is seen as fundamental for cooperation requirements to respect the sovereign rights of States over their natural resources and the bilateral approach to ABS. In addition, approaches to ABS differ greatly among countries, which makes cooperation difficult to put into effect" (p. 127). Cooperation is indeed futile as voluntary oligopolies fall apart (Samuelson \& Nordhaus, 2005); the biodiversity cartel would have to be compulsory (Vogel et al., 1997). Sovereignty would be interpreted as the right to deprive others of the right to negotiate bilateral Material Transfer Agreements (MTAs). Such an expression of the social contract parallels the "insurance mandate" of Obamacare in the U.S., which health-care economists find absolutely necessary for financial sustainability (Krugman, 2012).

Adaptation of the economics of information is nuanced for pathogens and also begins with the classification of the object accessed. It should not be "biological materials with human pathogenic potential" (Abbott, 2010) but "natural information of human pathogenic potential." Reduction to information extends the scope of ABS in both directions. For non-pathogenic natural information, biomimicry and non-human cultures (Vogel, 2011) are 
included even though neither exhibit a "biochemical compound," as stipulated in the definition of "derivative" in Art. 2(e) of the NP. For natural information of pathogenic potential, prions and heretofore unimagined menaces are included even though not strictly "resulting from the genetic expression or metabolism of biological or genetic resources." Compression continues with a re-examination of overarching objectives in the international conventions. The Parties to the CBD want in situ conservation; the Parties to the WHO, the exact opposite, viz., in situ eradication. Because timely data is of essence in public health (Cole, 2012), an efficient ABS policy should expedite samples into the international stream of R\&D. By the nature of information, be it natural or artificial, once the first sample is sequenced, exact copies subsequently submitted are redundant. But pathogens mutate and few subsequent submissions will be exact. Therefore, ABS policy should skew the reward heavily toward the first provider of a sample of natural information with pathogenic potential. Like the patent system itself, a first-to-submit principle would reign, albeit nuanced to also reward mutations. Countries, which suffer outbreaks late or simply procrastinate, would share fewer benefits. The asymmetry in the policy implications for ABS between natural information of pathogenic and non-pathogenic potential reflects the asymmetry in the objectives of the international conventions and coheres with "The General Theory of Second Best" (Lipsey \& Lancaster, 1956, 1957).

\section{Method}

Among the various stakeholders, scientists who research natural information with pathogenic potential have the most at stake from an efficient and equitable ABS policy, the victims of pandemics notwithstanding. Two hundred scientists were contacted in June 2012 from the electronic addresses drawn randomly from 556 multi-authored articles appearing in issues of Public Library of Science Pathogens (PLOS Pathogens) from 2011. The sample was divided equally into control and target groups. The subjects were coded (1-100 (c) or (t)) and the messages were addressed to the scientists by name.

The control group was informed with a brief introduction of the principal investigators and a bare-bones overview of the survey instrument (Box 1). The target group received the same message with three abstracts that elaborated the application of the economics of information and links to the corresponding open access articles (Box 2). The message establishes exposure to the existence of the argument regardless of whether or not they read the articles or even the abstracts. Boilerplate language for Prior Informed Consent (PIC), according to criteria of the United States National Institutes of Health, followed the text in both the control and target messages (Box 3). Tellingly, a close reading of the PIC would entail as much time for the respondents as completion of the actual survey.

The design of the survey reflected the general suspicion of economics-the-profession toward surveys themselves. "The central message in Milton Friedman's extremely influential essay, 'The Methodology of Positive Economics' (1953) is that the only relevant data are market data. Surveys are, Friedman maintains, worthless and irrelevant" (Hausman, 1995). One need only imagine the truthfulness of answers to a customer survey which asks "How much are you willing to pay?" Similarly, one would doubt the answers to the following pertinent questions: "Have you imported pathogenic organisms from other countries in the past year?" "Was ABS considered at any stage in planning the project?" "Do you believe an isolate or strain of a pathogen belongs to the biotic patrimony of the country in which it is found?"

The economics of information implies bounded openness for pathogens regardless of whether or not the scientist imports pathogens, disregards ABS and/or embraces the sovereignty of countries over genetic resources. Is mere exposure to its deductions sufficient to persuade (the target group)? Or is such exposure unnecessary in the formation of opinion on ABS (the control group)? The null hypothesis is that the target and control belong to the same population, i.e., exposure to the economics of information is not necessary. If control and target groups belong to the same population, then the results for each group can be summed to test whether the strength of the opinion differs from neutrality. In interpreting the data, the p-value tests the likelihood of the sample results assuming that the null hypothesis is true. For each question, responses were limited to the categories "strongly agree" (weight 3), "moderately agree" (2), "slightly agree" (1), "slightly disagree" (-1), "moderately disagree" $(-2)$, "strongly disagree" (-3). The option of "undecided" (0) was not offered. Categories are used in the survey as intensity of agreement is usually not conceived numerically. Nevertheless, numbers are needed to carry out hypothesis testing. The assumption behind assigning numbers to categories is that participants infer a linear gradation in the choices running from "strongly agree" to "strongly disagree."

Because the initial response to the 200 emails was very low (one percent), a provocative follow-up message was mailed (Box 4). The last opportunity to respond was embedded in a thank-you message for all who participated. 
In total, 26 scientists responded to the survey and another 12 communicated that they would decline. The engagement of 38 scientists brings the percentage to 19 .

\section{Results}

\subsection{Question 1}

Scientists who work with pathogens should be consulted on access and the sharing of benefits (ABS). Their opinions should influence policymaking.

Table 1. Results Question 1

\begin{tabular}{lccc}
\hline & Control & Target & Combined \\
\hline Mean $(\mu)$ & 2.67 & 2.64 & 2.65 \\
Sample variance $\left(\sigma^{2}\right)$ & 0.38 & 0.45 & 0.39 \\
Responses $(\mathrm{n})$ & 15 & 11 & 26 \\
p-value $\mu_{\mathrm{c}}=\mu_{\mathrm{t}}$ & \multicolumn{2}{c}{0.91} & \\
p-value $\mu_{\text {combined }}=0$ & & & 0.00 \\
\hline
\end{tabular}

\subsection{Question 2}

Economics is defined as "the study of how societies use scarce resources to produce valuable commodities and distribute them among different people" (Samuelson \& Nordhaus, 2005). For policymaking on "access and the sharing of benefits" (ABS) the economics should shape the law rather than the law shape "how societies use genetic resources".

Table 2. Results Question 2

\begin{tabular}{lccc}
\hline & Control & Target & Combined \\
\hline Mean $(\mu)$ & 1.00 & 0.64 & 0.84 \\
Sample variance $\left(\sigma^{2}\right)$ & 2.86 & 3.85 & 3.17 \\
Responses $(\mathrm{n})$ & 15 & 11 & 26 \\
p-value $\mu_{\mathrm{c}}=\mu_{\mathrm{t}}$ & \multicolumn{3}{c}{0.62} \\
p-value $\mu_{\text {combined }}=0$ & & & 0.02 \\
\hline
\end{tabular}

\subsection{Question 3}

The 2010 Nagoya Protocol to the Convention on Biological Diversity (CBD) adopts the CBD definition of genetic resources as "material." In 1970, Francis Crick published the "Central Dogma of Molecular Biology" which identified DNA as information and ever since "genetic information" has been a ubiquitous term in the scientific literature. The CBD classification of genetic resources as "material" appears to be a foundational flaw for policymaking.

Table 3. Results Question 3

\begin{tabular}{|c|c|c|c|}
\hline & Control & Target & Combined \\
\hline Mean $(\mu)$ & 1.87 & 0.82 & 1.42 \\
\hline Sample variance $\left(\sigma^{2}\right)$ & 2.5 & 3.76 & 3.05 \\
\hline Responses (n) & 15 & 11 & 26 \\
\hline p-value $\mu_{\mathrm{c}}=\mu_{\mathrm{t}}$ & \multicolumn{2}{|c|}{0.13} & \\
\hline $\mathrm{p}$-value $\mu_{\text {combined }}=0$ & & & 0.00 \\
\hline
\end{tabular}




\subsection{Question 4}

"Of The Division of Labor" was the first chapter of Adam Smith's the Wealth of Nations (1776). Specialization can also apply to economics itself. Economists have won Nobel Memorial Prizes with mention of their work on "the economics of information" in both 1982 and 2001. It makes sense to apply "the economics of information" to policymaking on access and benefit sharing (ABS).

Table 4. Results Question 4

\begin{tabular}{lccc}
\hline & Control & Target & Combined \\
\hline Mean $(\mu)$ & 1.54 & 1.5 & 1.52 \\
Sample variance $\left(\sigma^{2}\right)$ & 2.43 & 1.38 & 1.90 \\
Responses $(\mathrm{n})$ & 13 & 10 & 23 \\
p-value $\mu_{\mathrm{c}}=\mu_{\mathrm{t}}$ & & 0.95 & \\
p-value $\mu_{\text {combined }}=0$ & & & \\
\hline
\end{tabular}

\subsection{Question 5}

The provocative metaphor of The Gridlock Economy (2004) by Michael Heller is clarified in the subtitle How too Much Ownership Wrecks Markets, Stops Innovation, and Costs Lives. The core argument is that the transactions costs of negotiating property can become insurmountable. Such fears arose with the announcement of the Indonesian government in 2007 to withhold samples of H5N1 virus (avian flu) from WHO researchers. Ronald Coase won the 1991 Nobel Memorial Prize for "the economics of transaction costs." It makes sense to apply "the economics of transaction costs" to pathogenic material and the sharing of benefits (ABS) for pathogenic material.

Table 5. Results Question 5

\begin{tabular}{lccc}
\hline & Control & Target & Combined \\
\hline Mean $(\mu)$ & 1.33 & 1.10 & 1.30 \\
Sample variance $(\sigma 2)$ & 3.77 & 3.87 & 3.67 \\
Responses $(\mathrm{n})$ & 12 & 10 & 22 \\
p-value $\mu_{\mathrm{c}}=\mu_{\mathrm{t}}$ & & 0.79 & \\
p-value $\mu_{\text {combined }}=0$ & & & 0.00 \\
\hline
\end{tabular}

\subsection{Question 6}

Due to the transaction cost of negotiating licenses, the benefit for supplying pathogens cannot be royalties from patenting the genetic sequence of the pathogens supplied.

Table 6. Results Question 6

\begin{tabular}{lccc}
\hline & Control & Target & Combined \\
\hline Mean $(\mu)$ & 2.15 & 1.50 & 2.04 \\
Sample variance $\left(\sigma^{2}\right)$ & 1.97 & 2.05 & 1.38 \\
Responses $(\mathrm{n})$ & 13 & 10 & 23 \\
p-value $\mu_{\mathrm{c}}=\mu_{\mathrm{t}}$ & \multicolumn{3}{c}{0.28} \\
$\mathrm{p}$-value $\mu_{\text {combined }}=0$ & & & 0.00 \\
\hline
\end{tabular}




\subsection{Question 7}

Exemption of access and benefit sharing (ABS) requirements for non-commercial research depends on whether a line can be drawn between commercial and non-commercial research. For R\&D on pathogenic material, such a line can be drawn.

Table 7. Results Question 7

\begin{tabular}{lccc}
\hline & Control & Target & Combined \\
\hline Mean $(\mu)$ & 2.31 & 0.78 & Not Applicable (N/A) \\
Sample variance $\left(\sigma^{2}\right)$ & 0.56 & 3.41 & N/A \\
Responses $(\mathrm{n})$ & 13 & 11 & N/A \\
p-value $\mu_{\mathrm{c}}=\mu_{\mathrm{t}}$ & & 0.01 & \\
$\mathrm{p}$-value $\mu_{\text {combined }}=0$ & & & \\
\hline
\end{tabular}

\subsection{Question 8}

An objective of the Convention on Biological Diversity (CBD) is the conservation of genetic resources in situ. An objective of public health is eradication of the human pathogen in situ. In light of such divergent objectives, policymaking must diverge for access to pathogens and benefit sharing (ABS).

Table 8. Results Question 8

\begin{tabular}{lccc}
\hline & Control & Target & Combined \\
\hline Mean $(\mu)$ & 2.00 & 1.55 & 1.78 \\
Sample variance $\left(\sigma^{2}\right)$ & 1.45 & 1.67 & 1.54 \\
Responses $(\mathrm{n})$ & 12 & 11 & 23 \\
p-value $\mu_{\mathrm{c}}=\mu_{\mathrm{t}}$ & \multicolumn{3}{c}{0.39} \\
p-value $\mu_{\text {combined }}=0$ & & & 0.00 \\
\hline
\end{tabular}

\subsection{Question 9}

Pathogens are peculiar genetic resources for access and the sharing of benefits (ABS). Every country could become a country of origin. Because delays in R\&D can conceivably translate into pandemics, benefits from sharing human pathogens should be on a first-to-submit principle into the International R\&D pipeline.

Table 9. Results Question 9

\begin{tabular}{lccc}
\hline & Control & Target & Combined \\
\hline Mean $(\mu)$ & 1.50 & 1.45 & 1.47 \\
Sample variance $\left(\sigma^{2}\right)$ & 2.63 & 4.27 & 3.26 \\
Responses $(\mathrm{n})$ & 12 & 11 & 23 \\
p-value $\mu_{\mathrm{c}}=\mu_{\mathrm{t}}$ & \multicolumn{2}{c}{0.95} & \\
p-value $\mu_{\text {combined }}=0$ & & & \\
\hline
\end{tabular}

\subsection{Question 10}

The Survey has helped me re-think my position regarding access to genetic resources and the fair and equitable sharing of benefits. 
Table 10. Results Question 10

\begin{tabular}{lccc}
\hline & Control & Target & Combined \\
\hline Mean $(\mu)$ & 0.50 & 1.00 & 0.72 \\
Sample variance $\left(\sigma^{2}\right)$ & 3.34 & 2.60 & 2.96 \\
Responses $(\mathrm{n})$ & 14 & 11 & 25 \\
p-value $\mu_{\mathrm{c}}=\mu_{\mathrm{t}}$ & \multicolumn{2}{c}{0.48} & \\
$\mathrm{n}$-value $\mu_{\text {combined }}=0$ & & & 0.04 \\
\hline
\end{tabular}

\section{Discussion}

The survey coheres with the broad outline of the application of the economics of information to ABS. Both the least and most surprising result was the strong agreement $\left(\mu_{\text {combined }}=2.65, \sigma^{2}=0.39\right)$ to the first question about inclusion of scientists in policymaking. The result is not surprising inasmuch as the research agenda of scientists who work with pathogens is encumbered by ABS requirements. The result is surprising inasmuch as deference to authority largely accounts for the historical success of public vaccination programs (Allen, 2007). Although scientists who work with pathogens feel strongly that they should be consulted, some $87 \%$ did not respond to the ten-minute survey despite being the contact author listed in an article published in PLoS Pathogens in 2011. Three scientists declined due to the complexity of the topic. One objected to the inference that low participation rates would justify non-consultation. Another took the liberty to denigrate the "research" (quotations his) with ad hominen remarks about the lead author. The near equivalence of responses for both target and control groups (p-value $\mu_{\mathrm{c}}=\mu_{\mathrm{t}} 0.91$ ) is the first indicator that exposure to the economics of information makes no difference on the sample result.

The second question builds upon the tacit assumption of the first: division of intellectual labor. Any textbook definition of economics leads one to believe that the legal framework of resource allocation should be driven by economics and not vice versa. Respondents only slightly agree $\left(\mu_{\text {combined }}=0.84, \sigma^{2}=3.17\right)$. The variance seems especially high in light of the low variance to the first question. Like the first question, the result does not depend on exposure to the economics of information ( $\mathrm{p}$-value $\mu_{\mathrm{c}}=\mu_{\mathrm{t}}$ 0.62). However, one must reject the null hypothesis at the $5 \%$ confidence level for the combined ( $\mathrm{p}$-value $\mu_{\text {combined }}=00.02$ ). An irony emerges: the responses to the remaining questions correspond to the implications of the economics of information even though respondents do not agree that economics should shape the law.

Results to the third question were also surprising $\left(\mu_{\text {combined }}=1.42, \sigma^{2}=3.05\right)$. Definitions are foundational for public policy and the definition of "genetic resource" as "material" in Art. 2 of the CBD is unambiguously wrong. Ostensibly all the scientists surveyed are knowledgeable of genomics, proteomics, metabolomics and related fields. All should "strongly agree." The mean may reflect a reluctance to criticize a UN environmental convention for which sympathies abound, which reinforces Friedman's dismissal of survey data. However, the high variance indicates that many scientists exhibit no such reticence to disagree. Exposure to the economics of information makes no difference on the sample result ( $p$-value $\mu_{\mathrm{c}}=\mu_{\mathrm{t}} 0.13$ )

The fourth question attempts to legitimize the economics of information with the authority of two Nobel Memorial Prizes. The moderate agreement is a hopeful sign that the economics of information will resonate for ABS policy $\left(\mu_{\text {combined }}=1.52, \sigma^{2}=1.90\right)$. The same distribution between target and control groups $\left(p-v a l u e ~ \mu_{c}=\mu_{t}\right.$ 0.95 ) lends strong evidence that exposure to the economics of information makes no difference on the sample result.

The fifth question extends the line of reasoning of the fourth. Just as there is an economics of information worthy of a Nobel, so too is there an economics of transaction costs. Nevertheless, the results are more ambiguous regarding its applicability $\left(\mu_{\text {combined }}=1.30, \sigma^{2}=3.67\right.$ ). Exposure to the economics of information makes no difference on the sample result ( $\mathrm{p}$-value $\mu_{\mathrm{c}}=\mu_{\mathrm{t}} 0.79$ ).

Question Six begins with the non-controversial premise that negotiating licenses entails transaction costs. The responses reveal the perceived extent of those costs. The moderate agreement and variance $\left(\mu_{\text {combined }}=2.04, \sigma^{2}=\right.$ 1.38) bolsters the policy implication of bounded openness. Exposure to the economics of information makes no difference on the sample result ( $\mathrm{p}$-value $\mu_{\mathrm{c}}=\mu_{\mathrm{t}} 0.28$ ).

The response to the seventh question is both expected and unexpected. With mere exposure to the argument, more respondents realize that no line can be drawn between commercial and non-commercial research as 
evidenced by the lower mean and higher variance in the target $\left(\mu_{\mathrm{t}}=0.78, \sigma^{2}=3.41\right)$ than the control group $\left(\mu_{\mathrm{c}}=\right.$ $2.31, \sigma^{2}=0.56$ ). As the null hypothesis is rejected at the $5 \%$ confidence level ( $p$-value $\mu_{c}=\mu_{t} 0.01$ ), exposure to the economics of information has changed opinion on ABS in the expected direction. But exposure is not enough The target group still slightly agrees that a line can be drawn while knowledgeable commentators perceive only a "fine line, in practical terms between research for commercial and non-commercial purposes" (Vivas-Eugui, 2012). Moreover, the line disappears as soon as "changes of intent" enter the "mutually agreed terms" of MTAs.

The eighth question brings to the fore an issue that is seldom addressed headlong: the respective objectives of the CBD and WHO are diametrically opposed for genetic resources. The respondents moderately agree with moderate variance that policymaking must also diverge $\left(\mu_{\text {combined }}=1.78, \sigma^{2}=1.54\right)$. Perhaps a stronger opinion did not emerge due to the wording "must diverge." Some respondents may have conceded the possibility of exceptions, albeit unimagined. Exposure to the economics of information makes no difference on the sample result ( $\mathrm{p}$-value $\mu_{\mathrm{c}}=\mu_{\mathrm{t}} 0.39$ ).

The preceding eight questions lay the groundwork for the core policy recommendation embedded in the ninth: benefits from sharing human pathogens should be on a first-to-submit principle into the international R\&D pipeline. Although the respondents only slightly agree, the high variance is reason for hope $\left(\mu_{\text {combined }}=1.47, \sigma^{2}=\right.$ 3.26). Similarly hopeful is that exposure to the economics of information makes no difference on the sample result (p-value $\left.\mu_{\mathrm{c}}=\mu_{\mathrm{t}} 0.95\right)$.

At a superficial level, the tenth question addresses the Prior Informed Consent of the survey. Did any benefits accrue to the respondents as a result of being surveyed (see "Incentives" in Box 3)? The existence of benefits $\left(\mu_{\text {combined }}=0.72, \sigma^{2}=2.96\right)$ coheres with the results from Question Seven and one rejects the null hypothesis for the combined values ( $\mathrm{p}$-value $\mu_{\text {combined }}=00.04$ ). Exposure to the economics of information also makes no difference on the sample result ( $\mathrm{p}$-value $\mu_{\mathrm{c}}=\mu_{\mathrm{t}} 0.48$ ).

\section{Conclusion}

The discussion over ABS in the COPs reifies negotiations between industrial users and provider countries as only bilateral. The consequences are predictable and were indeed predicted: unfair and inequitable sharing of benefits and insurmountable transaction costs for MTAs. A multilateral alternative appeared repeatedly in the literature since 1992, the same year as the signing of the CBD at the historic Earth Summit in Rio de Janeiro. Nevertheless, the Parties to the CBD proceeded with a naive sense of sovereignty. The notion of "sunk costs" (i.e., don't spend good money after bad) has also proven elusive. The economics of information would remain studiously ignored.

The hurdle now posed by the ABS requirements for scientists who work with pathogens parallels the hurdle posed for scientists who work with taxonomic samples. Like the WHO, the International Barcode of Life (iBOL) has argued, unsuccessfully, for exemption from the ABS requirements of the CBD. Ironically, the application of the economics of information behooves both the $\mathrm{WHO}$ and iBOL beyond merely overcoming the hurdle of ABS. For iBOL, bounded openness requires a gargantuan database the fixed costs of which would be financed through royalties on ubiquitous natural information (Vernooy et al., 2010; Vogel, 1994). Such serendipity also holds for scientists who work with natural information of pathogenic potential. Bounded openness foresees benefits on a first-to-submit principle thereby expediting samples into the international R\&D research stream. The derivation constitutes a capstone application of the economics of information.

Could scientists who work with pathogens become part of a coalition that supports the application of the economics of information to the CBD? The argument has been reduced to ten questions applied in an electronic survey. Responses to the questions correspond to varying degrees with the policy implications of the economics of information. Overwhelmingly the respondents did not differ in opinion due to exposure to the argument (the exception being the line drawn between commercial and non-commercial research) even though the survey helped to re-think opinions. So, the answer to the above question is affirmative in the extreme, especially if one assumes that the target group did not bother to read either the articles or the abstracts.

A Nobel Prize carries cachet even if only memorial. Two of the survey questions reference Nobel Memorial Laureates whose contributions to economics dovetail with the implication of bounded openness for ABS. One economist who almost won--John Kenneth Galbraith--identified long ago the only real mechanism for policy reform: "countervailing power" (Drum, 2011). The survey results indicate that umbrella organizations for scientists who work with pathogens should ally themselves with similarly disadvantaged stakeholders in the ongoing Conferences of the Parties to the Convention on Biological Diversity and the Nagoya Protocol. 


\section{Acknowledgments}

Comments to early drafts by Klaus Angerer, Paul Bayman, Steven E. Massey, and Manuel Ruiz were especially appreciated. We are most grateful to the participants of the survey.

\section{References}

Abbott, F. M. (2010). An international legal framework for the sharing of pathogens: issues and challenges. ICTSD's Programme on IPRs and Sustainable Development, Issue Paper No. 30. Geneva, Switzerland: International Centre for Trade and Sustainable Development. http://dx.doi.org/10.7215/IP_IP_20101021

Allen, A. (2007). Vaccine. New York: W. W. Norton \& Company.

Buck, M., \& Hamilton, C. (2011). The Nagoya Protocol on access to genetic resources and the fair and equitable sharing of benefits arising from their utilization to the convention on biological diversity. Review of European Community \& International Environmental Law, 20(1), 47-61. $\mathrm{http}: / / \mathrm{dx}$. doi.org/10.1111/j.1467-9388.2011.00703.x

Cole, A. (2012). Disease sleuths search for outbreaks online. National Public Radio.

Convention on Biological Diversity, Rio de Janeiro. (1992). Retrieved from http://www.cbd.int/convention/text/

Crick, F. (1970). Central dogma of molecular biology. Nature, 227, 561-563. http://dx.doi.org/10.1038/227561a0

Drum, K. (2011). James Galbraith on Countervailing Powers, Mother Jones. Retrieved from http://www.motherjones.com/kevin-drum/2011/02/james-galbraith-countervailing-powers

Friedman, M. (1966). The methodology of positive economics. In Essays in positive economics. Chicago: University of Chicago Press.

Hardin, G. (1993). Living Within Limits. New York: Oxford University Press.

Hausman, D. M. (1995). Why does evidence matter so little to economic theory? In Structures and norms in science. Florence: The Tenth International Congress of Logic, Methodology and Philosophy of Science.

Heller, M. (2004). The Gridlock Economy. New York: Basics Books. Retrieved from http://www.npr.org/blogs/health/2012/02/07/146519243/disease-sleuths-surf-for-outbreaks-online

IUCN Environmental Policy and Law. (2012). The explanatory guide to the Nagoya Protocol on Access and Benefit-Sharing Draft 3.0. Retrieved from http://cmsdata.iucn.org/downloads/iucn_explanatory_guide_to_the_nagoya_protocol_draft_3_0.pdf

Kamau, E. C. Fedder, B., \& Winter, G. (2010). The Nagoya Protocol on access to genetic resources and benefit sharing: what is new and what are the implications for provider and user countries and the scientific community? Law, Environment and Development Journal, 6(3), 51-65. Retrieved from http://www.lead-journal.org/content/10246.pdf

Krugman, P. (2011). Health Care Basics. The New York Times. Retrieved from http://krugman.blogs.nytimes.com/2011/01/17/health-care-basics/

Kuhn, T. (1962). The Structure of Scientific Revolutions. Chicago: University of Chicago Press.

Lawson, C., \& Hocking, B. A. (2010). Accessing and benefit sharing avian influenza viruses through the World Health Organisation: a CBD and TRIPS compromise thanks to Indonesia's sovereignty claim? In T. P. Pogge, M. Rimmer, \& K. Rubenstein (Eds.), Incentives for global public health: patent law and access to essential medicines (pp. 284-312). Cambridge: Cambridge University Press.

Lipsey, R. G., \& Lancaster, K. (1956-1957). The General Theory of Second Best. Review of Economic Studies, 24(1), 11-32. http://dx.doi.org/10.2307/2296233

Marrero-Girona, G., \& Vogel, J. H. (2012). "Can 'monkey business' resolve the most contentious issue in the Convention on Biological Diversity?". International Journal of Psychological Studies, 4(1), 55-65. http://dx.doi.org/10.5539/ijps.v4n1p55

May, C. (2010). The global political economy of intellectual property rights (2nd ed.). USA: Routledge.

Nagoya Protocol on Access to Genetic Resources and the Fair and Equitable Sharing of Benefits Arising from Their Utilization to the Convention on Biological Diversity, Nagoya. (2010). Retrieved from http://www.cbd.int/decision/cop/?id=12267

Oduardo-Sierra, O., Hocking, B. A., \& Vogel, J. H. (2012). Monitoring and tracking the economics of information in the Convention on Biological Diversity: studied ignorance (2002-2011). Journal of Politics 
and Law. http://dx.doi.org/10.5539/jpl.v5n2p29

Samuelson, P., \& Nordhaus, D. (2005). Economics (18th ed.). New York: McGraw-Hill.

Smith, A. (1776). Wealth of Nations. Retrieved from http://www.econlib.org/library/Smith/smWN.html

Vernooy R., Haribabu E., Muller M. R., Vogel J. H., \& Hebert P. D. N. (2010). Barcoding life to conserve biological diversity: beyond the taxonomic imperative. PLoS Biol., 8(7), e1000417. http://dx.doi.org/10.1371/journal.pbio.1000417

Vivas-Eugui, D. (2012). Bridging the gap on intellectual property and genetic resources in WIPO's Intergovernmental Committee (IGC). ICTSD's Programme on Innovation, Technology and Intellectual Property (34). Geneva, Switzerland: International Centre for Trade and Sustainable Development.

Vogel, J. H. (1994). Genes for Sale. New York: Oxford University Press.

Vogel, J. H. (1997). White Paper: the successful use of economic instruments to foster the sustainable use of biodiversity: six cases from Latin America and the Caribbean. Biopolicy Journal, 2(5). Retrieved from http://www.bioline.org.br/request?py97005

Vogel, J. H. (2000). The biodiversity cartel. Quito, Ecuador: CARE.

Vogel, J. H. (2009). iBOL as an Enabler of ABS and ABS as an Enabler of iBOL (pp. 38-47). Proceedings of the Seminar "Barcoding of Life: Society and Technology Dynamics-Global and National Perspectives".

Vogel, J. H., Álvarez-Berríos, N., Quiñones-Vilche, N., \& Medina-Muñiz, J. L. (2011). The economics of information, studiously ignored in the Nagoya Protocol on Access and Benefit Sharing". Law Environment and Development Journal, 7(1), 51-65. Retrieved from http://www.lead-journal.org/content/11052.pdf

West, S. (2012). Institutionalized exclusion: the political economy of benefit sharing and intellectual property. Law, Environment and Development Journal, 8(1), 19. Retrieved from http://www.lead-journal.org/content/12019.pdf

World Health Assembly Resolution. (2011). Pandemic influenza preparedness: sharing of influenza viruses and access to vaccines and other benefits. Sixty-fourth World Health Assembly. Retrieved from http://apps.who.int/gb/ebwha/pdf_files/WHA64/A64_R5-en.pdf 
Box 1: Invitation to Survey.

The contact authors received the message below. The bracketed text indicates the additional wording for the target group which also received the abstracts of four articles which apply the economics of information to

ABS

Subject: RE: Follow-Up to your 2011 PLoS Pathogens Article - (c)/(t) [Number in Sample]

Dear [Author Contact]

The Convention on Biological Diversity (CBD) applies to scientists who work with material of pathogenic potential (bacteria, fungi, helminthes, protozoa, viruses and prions). We are Barbara A. Hocking and Joseph Henry Vogel, professors of law and economics respectively. Our undergraduate research assistant is Claribel Fuentes-Rivera. We have constructed a ten-question MONKEY survey on "The Nagoya Protocol on the Fair and Equitable Sharing of Benefits Arising from the Utilization of Genetic Resources" to the CBD. The only purpose of the survey is to gauge the receptivity of scientists to the application of formal economics for policymaking. Our hope is to facilitate $R \& D$ on material with pathogenic potential and publish the results in an open-access journal before the 11th Conference of the Parties to the CBD in October 2012.

[A tentative abstract follows this message. For your reference, we also include three abstracts from recently published work which appeared in open-access journals. The third article "The Economics of Information, Studiously Ignored in the Nagoya Protocol" (LEAD J 2011) has already been translated into five languages and the open-access links are provided above each abstract.]

Would you be so kind to answer the ten-minute survey? Identities of all respondents will remain anonymous. We believe that you will find the questions engaging and perhaps even enlightening. Below the Xes is the standard text from the University of Puerto Rico-Rio Piedras for "prior informed consent" in conformity with the US National Institutes of Health.

With a simple reply "SUBJECT: YES" we will send the survey link.

Many thanks for any collaboration!

Joseph Henry Vogel, Barbara A. Hocking and Claribel Fuentes-Rivera

[A dashed line separated the message from the four abstracts cited in Box 2] 
Box 2: Citations of the Abstracts Incorporated at Bottom of Target Message

"Human Pathogens as Capstone Application of the Economics of Information to Convention on Biological Diversity", [The same abstract as above but with the omission of the last sentence and modification of the reference to first-to-submit principle with "nuanced" with benefits "greatest" rather than solely to the country of origin]

"Monitoring and Tracking the Economics of Information in the Convention on Biological Diversity: Studied Ignorance (2002-2011). Omar Oduardo, Barbara A. Hocking, Joseph Henry Vogel, Journal of Politics and Law, http://dx.doi.org/10.5539/jpl.v5n2p29 1 June 2012.

“Can 'Monkey Business' Resolve the Most Contentious Issue in the Convention on Biological Diversity?" Gabriel Marrero-Girona, Joseph Henry Vogel, International Journal of Psychological Studies, Volume 4 Number 1 March 2012, 55-65. doi:10.5539/ijps.v4n1p55 URL: http://dx.doi.org/10.5539/ijps.v4n1p55

"The Economics of Information, Studiously Ignored in the Nagoya Protocol on Access and Benefit Sharing" Joseph Henry Vogel, Nora Álvarez-Berríos, Norberto Quiñones-Vilche, Jeiger L. Medina-Muñiz, Dionisio Pérez-Montes, Arelis I. Arocho-Montes, Nicole Vale-Merniz, Ricardo Fuentes-Ramirez, Gabriel Marrero-Girona, Emmanuel Valcárcel Mercado, Julio Santiago-Rios, 7/1 Law Environment and Development (LEAD) Journal (2011), p. 51-65 available at:

English http://www.lead-journal.org/content/11052.pdf

Arabic: http://www.lead-journal.org/content/11052d.pdf

Chinese: http://www.lead-journal.org/content/11052e.pdf

French: http://www.lead-journal.org/content/11052b.pdf

Portuguese: http://www.lead-journal.org/content/11052c.pdf

Spanish: http://www.lead-journal.org/content/11052a.pdf 
Box 3: Prior Informed Consent

Description

You are invited to participate in a study conducted by Claribel Fuentes-Rivera, an undergraduate student of the Department of General Sciences in the Faculty of Natural Sciences, University of Puerto Rico-Rio Piedras (UPR-RP), under the supervision of Joseph Henry Vogel, also of the UPR-RP and Barbara A. Hocking, Professor of Law at the Queensland University of Technology. We hope to learn how researchers who work with material of pathogenic potential receive the application of the economics of information to the question of access to genetic resources and the sharing of benefits. You were selected as a possible participant in this study because of your authorship in an article published in 2011 in Public Library of Science Pathogens. If you decide to participate, we will send you a ten-question MONKEY survey. The number anticipated of participants is around 200 people and the survey should take 10 minutes. The questions are written for a target audience of research scientists and we believe that they constitute a benefit by triggering reflection on one of the most important policy issues for research on pathogens.

Risk and Benefits

As is customary in prior informed consent forms, we cannot guarantee, however that you will receive any benefits from this study. The risk associated is the time spent reflecting on the answers to the questions. Your decision whether or not to participate will not prejudice your future relations with the University of Puerto Rico-Río Piedras.

Confidentiality

The identity of the participants of the online survey will be protected. Any information that is obtained in connection with this study and that can be identified with you, will remain confidential and will be disclosed only with your permission or as required by law. For security, all personal information such as names and e-mails will only be accessed by the surveyor, Claribel Fuentes and the supervisor Prof. Joseph Vogel. Once the results are obtained, personal information will be erased.

The information managed in the computer can conceivably be accessed and revised by third persons who can have legitimate or illegitimate access to the computer and its content; examples include supervisors, hackers, relatives, etc. There is also the possibility that the information may remain on the computer and be accessed through internet.

Officials of the University of Puerto Rico-Río Piedras and the federal agencies responsible of maintaining integrity of surveys could conceivably request the data obtained during the study, including this document. 


\section{Box 4: First Reminder}

Dear Dr. [Author Contact],

As a follow-up to your 2011 PLoS Pathogens article, our group sent an email four weeks ago to enquire whether you would be so kind as to respond to a ten-question e-survey about access to genetic resources as established under the UN Convention on Biological Diversity. Although public policy on access will impact all scientists who research pathogens, empirical evidence is lacking regarding their views. So, the survey begins with

"Scientists who work with pathogens should be consulted on access and the sharing of benefits (ABS). Their opinions should influence policymaking."

“strongly agree" "moderately agree" "slightly agree" "slightly disagree" "moderately disagree" "strongly disagree".

We have contacted two hundred research scientists who published in PLoS Pathogens in 2011. Should the response rate to the survey be less than $15 \%$, a reasonable (albeit unfortunate) inference is that scientists who work with pathogens should not be consulted.

If you wish to participate in the survey, please click on the following link.

[monkey survey link]

We do not believe the survey will take more than 10 minutes. We thank you for your cooperation and aim to publish our findings in an open access journal.

Sincerely,

Joseph Henry VOGEL, PhD

Professor of Economics

University of Puerto Rico-Río Piedras 